\title{
EDITORIAL
}

\section{Bone marrow progenitors in inflammation and repair: new vistas in respiratory biology and pathophysiology}

\author{
J.A. Denburg* and S.F. van Eeden\#
}

\section{INTRODUCTION \\ Bone marrow-derived stem cells}

Respiratory and allergic/immune diseases such as asthma, chronic obstructive pulmonary disease (COPD), pulmonary fibrosis, cystic fibrosis, and acute and chronic lung infections are leading causes of morbidity and mortality in Canada as well as globally. Inflammatory pathology is central to all of these diseases, recently recognised to include systemic processes involving the active recruitment and differentiation of bone marrow-derived haemopoietic and nonhaemopoietic "progenitors" (termed BMSC). These cells have the potential to differentiate into a diversity of cell types found in normal tissue [1-4], as well as to contribute to repair and remodelling following lung injury. Recently, it has been proposed that circulating BMSC can "sense" injured tissue, and undergo migration and recruitment to sites of tissue damage. Here they can differentiate into inflammatory effector cells (such as neutrophils, eosinophils, basophils, mast cells and monocytes), or nonhaemopoietic cells that can promote structural and functional tissue repair, revealing the plasticity of these pluripotent cell populations [5] and their participation in regenerative and/or inflammatory processes. Within tissues, the fate of haemopoietic progenitors is determined by locally elaborated growth factors that permit a process termed "in situ haemopoiesis" [6-9]. This leads to the accumulation of inflammatory effector cells, immunocompetent cells and tissue structural cells (e.g. dendritic and endothelial cells).

\section{Markers of BMSC}

A critically important marker of haemopoietic progenitors in the marrow, circulatory and tissue compartments [10-13] is the CD34 antigen. This is an integral membrane differentiation stage-specic glycoprotein that is expressed on the majority of immature haemopoietic cells [14, 15]. It is also expressed on tissue structural cells, including fibroblasts and vascular endothelial cells $[15,16]$, functioning to regulate adhesion of these cells to haemopoietic inductive microenvironmental stroma and, presumably, to other elements in blood vessels and peripheral tissues [17]. The CD34-knock out mouse models have revealed a down-modulation of leukocyte

*Faculty of Health Sciences, McMaster University, Hamilton, ON, and ${ }^{\#}$ The James Hogg iCAPTURE Centre for Cardiovascular and Pulmonary Research, St. Paul's Hospital, Vancouver, BC, Canada

CORRESPONDENCE: J.A. Denburg, Faculty of Health Sciences, McMaster University, Hamilton, ON L8N 3Z5, Canada. Fax: 19055214971. E-mail: denburg@mcmaster.ca trafficking [18] and a reduction of numbers of myeloid progenitor cells [19].

\section{BMSC IN LUNG AND AIRWAYS INFLAMMATION Mobilisation of BMSC}

A brisk bone marrow response that includes the release of immature cells has been documented during the course of a variety of inflammatory events in the lung, such as pneumonia, endotoxaemia, cigarette smoking, asthma and exposure to air pollutants [20-27]. Studies in bacterial pneumonia showed increased circulating levels of bone marrow-derived progenitors of endothelial cells (AC133+ cells or endothelial progenitor cells (EPCs)). Subjects with low EPC counts tend to have persistent fibrotic changes in their lungs after recovery from pneumonia [28]. This suggests that BMSC contribute to lung repair following infection. Since emphysema is characterised by the destruction of alveolar walls, defective repair following injury (by cigarette smoke) has been postulated as a potential mechanism for the development of emphysema. The very interesting study by PALANGE et al. [29] in the current issue of the European Respiratory Journal shows a $>50 \%$ decrease in circulating levels of haemopoietic progenitors (CD34+ cells) and EPCs in subjects with severe COPD. The study also demonstrates a relationship between disease severity (airways obstruction or forced expiratory volume in one second/forced vital capacity ratio) and circulating progenitors, suggesting that this could imply a defective BMSC response as a critical determinant of the pathogenesis of COPD. An alternative interpretation of their findings is that decreased numbers of circulating progenitors in circulation are a result of ongoing BMSC recruitment into, and sequestration in, inflamed lung tissue. Unfortunately, the authors do not seriously consider the latter possibility (see below), leaning almost exclusively towards a postulate of decreased bone marrow production and/or release of stem cells in COPD.

Circulating levels of pro-inflammatory and haemopoietic growth factors, e.g. interleukin (IL)-6, IL-8 and granulocyte colony-stimulating factor (GC-SF), are elevated during acute community-acquired pneumonia [30]. Several of these inflammatory mediators, generated locally and translocated systemically during acute and chronic airways inflammation, constitute critical mediators (granulocyte-macrophage colonystimulating factor, GC-SF, macrophage colony-stimulating factor, IL-5 to IL-8, IL-12 and macrophage inflammatory protein-1 $\alpha$ ) in the release, trafficking and differentiation of BMSC [31-38] (fig. 1). 


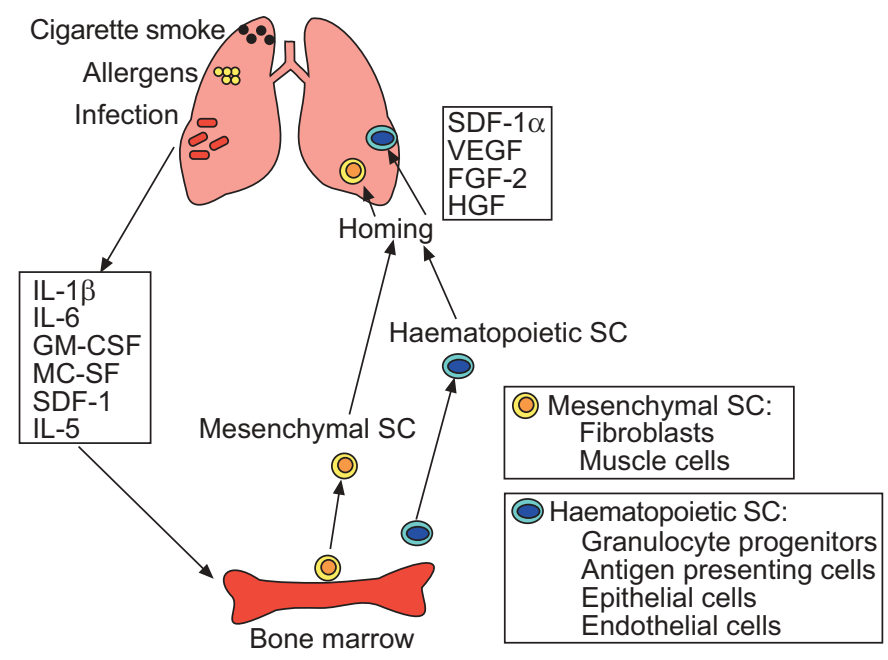

FIGURE 1. Schematic diagram to show lung inflammation induced by stimuli, which generates mediators that stimulate the bone marrow to produce and release haematopoietic and mesenchymal stem cells (SC). The bone marrow-derived SCs are involved in the regulation of the inflammatory response. SDF: stromal-derived factor; VEGF: vascular endothelial growth factor; FGF: fibroblast growth factor; HGP: hepatocyte growth factor; IL: interleukin; GM-CSF: granulocyte-macrophage colony-stimulating factor; MC-SF: macrophage-colony-stimulating factor.

\section{Homing of BMSC to the lung and airways}

Mesenchymal stem cells express a unique set of chemokine receptors that are thought to be involved in the homing of these cells to tissues [39]. Mediators such as plasma stromalderived factor (SDF)- $1 \alpha$ have been shown to promote homing of stem cells to the marrow [3]. SDF-1 $\alpha$, vascular endothelial growth factor (VEGF)-A and fibroblast growth factor-2 are elevated following myocardial injury and postulated to promote homing of EPCs into damaged myocardium [40]. In an animal model, lung injury induced by irradiation, combined with elastase digestion, increased the homing of these BMSCs into the lung [41]. This suggests that local production of homing factors in the lung promotes recruitment of BMSC into damaged lung tissues, and that BMSC contribute to modulation of airway inflammatory responses. PALANGE et al. [29] note that neither hepatocyte growth factor nor VEGF, crucial for recruitment and effective epithelial and endothelial repair in the lung [42], were decreased in their COPD group, suggesting effective homing and recruitment of BMSC into lung tissues. Differences in BMSC dynamics among various airways conditions such as pneumonia [28], interstitial lung disease $[41,43]$, and COPD may be due to differences in the nature and severity of the inflammatory/injurious stimulus.

\section{BMSC IN ALLERGIC DISEASE}

$B M S C$ in the maintenance of allergic airways inflammation Accumulation of eosinophils and basophils in tissues is characteristic of allergic inflammation in rhinitis, nasal polyposis and asthma. These airway tissue inflammatory events are coincident with relevant changes and fluctuations of circulating and marrow populations of eosinophil-basophil (Eo/B) progenitors [44-49], including upregulation of IL-5R $\alpha$ and CCR3 (eotaxin receptor) and CXCR4 (SDF-1 receptor, on bone marrow as well as airways tissue CD34+ cells) [11, 50-53]. The latter axis plays a critical role in adult haemopoietic stem cell homing, as it does during embryogenesis [54]. The functional consequence of increased levels of progenitors in numerous compartments highlights the multiple levels at which BMSC can respond to allergic stimuli. The results are consistent with the hypothesis that eosinophils and basophils accumulate at sites of allergic reactions, at least in part, by recruitment of progenitors from circulation and bone marrow, under the influence of tissue-elaborated haemopoietic cytokines and chemokines.

Relevant to these considerations, and critical to the interpretation of the findings of PALANGE et al. [29], there is documentation of consistent and dramatic decreases in circulating Eo/B colony-forming units (CFUs) in subjects with allergic airway (rhinitis and asthma) symptoms during the peak of seasonal aero-allergen (i.e. continual, daily) exposure [55-57], with numbers rising again post-seasonally. This has led to the hypothesis of a high-turnover state of these progenitors, with increased trafficking to tissues and their differentiation in situ. Further support of this concept comes from observations in a model of controlled withdrawal of inhaled corticosteroids to provoke a mild asthma exacerbation. Circulating Eo/B CFU rise and are then restored to baseline or lower with reinstitution of disease-controlling inhaled therapy, suggesting that progenitor fluctuations contribute to tissue inflammation, and are responsive to tissue signals as well as to topical corticosteroid therapy [57-59]. This view is strengthened by the following findings. 1) CD34-immunopositive/IL-5 receptor- $\alpha$ mRNA+ cells are detectable in lung biopsies from atopic asthmatics [51]. 2) An ex vivo allergen challenge of nasal explant tissue from allergic rhinitis demonstrates IL-5-driven eosinophil differentiation [60]. 3) In mouse models of allergeninduced airway eosinophilia, increased numbers of IL-5responsive Eo/B-CFU can be grown from lung-extracted progenitors following allergen challenge compared with saline challenge [13]. Additionally, bone marrow progenitors are upregulated in the airway after allergen inhalation [61, 62], a process which is dependent on IL-5 and eotaxin [63-66].

\section{BMSC in the development of allergy and asthma}

There is now a burgeoning body of evidence showing that activation of selective haemopoietic processes is not only associated with the onset and maintenance of allergic inflammation in atopic adults, but also with the development of the allergic disease in infants. Functional and phenotypical progenitor alterations relevant to Eo/B lineage commitment have been observed in neonates at risk for atopy and asthma $[67,68]$. This area promises to be of great interest in understanding the role and fate of the very abundant CD34+ BMSC populations present in cord blood at birth.

\section{BMSC IN LUNG REPAIR}

KRAUSE et al. [4] have shown that injected BMSC can be detected in recipient lung tissue as fibroblast-type cells or bronchial epithelial cells and type I \& II pneumocytes $[69,70]$. Several studies have shown that BMSC can differentiate into lung cells in mice [4, 70-73] as bronchial epithelial cells [4], type I alveolar epithelial cells [70] and type II alveolar epithelial cells $[4,71]$. In human studies after haemopoietic stem cell transplantation, "chimerism" of epithelial and endothelial cells has been reported in recipients [74, 75]. 
Traditionally, type II alveolar epithelial cells have been believed to be progenitor cells of type I cells [76, 77], but recently ABE et al. [78] showed that type I alveolar epithelial cells could be derived from circulating stem cells. WANG et al. [79] recently demonstrated that genetically corrected bone marrow-derived mesenchymal cells from cystic fibrosis patients differentiate into airway epithelial cells, suggesting this as a potential therapy for these patients. The epithelium itself contains cells with properties of progenitor cells [76, 8083] and, like BMSC, these cells may reside in niches. Key unanswered questions regarding the regeneration of lung epithelial cells include the following. 1) What progenitor cells initiate airway and alveolar epithelial repair? 2) What markers identify these cells? 3) What is the relative contribution of resident epithelial progenitors versus BMSC, e.g. does the relative contribution vary with the nature of the injury and/or the presence of underlying disease?

\section{BMSC-BASED THERAPEUTICS}

BMSC constitute a double-edged sword. Potentially, they could promote lung and airways inflammation and tissue damage by providing pro-inflammatory effector cells such as eosinophils or neutrophils. Alternatively, there is mounting evidence that BMSC may be useful, if not as true stem cells then at least as vehicles for emerging cell and gene therapies, especially in the field of tissue engineering. BMSC with mesenchymal stem cell characteristics are capable of differentiating along multiple lineages in vitro and in vivo and have significant expansion capability [1-4, 69-71, 84-87].

Promising studies have shown that these cells from the bone marrow can repair damaged muscle cells $[85,86]$, revascularise ischemic myocardium [86], differentiate into micro- and macroglia in the brain [87], and replace liver cells [71] and lung cells $[4,69,70]$. Regulating and promoting this process offers a novel cell-based therapeutic option for regeneration and repair of lung tissues.

\section{REFERENCES}

1 Prockop DJ. Marrow stromal cells as stem cells for nonhematopoietic tissues. Science 1997; 276: 71-74.

2 Bianco P, Gehron RP. Marrow stromal stem cells. J Clin Invest 2000; 105: 1663-1668.

3 To LB, Haylock DN, Simmons PJ, Juttner CA. The biology and clinical uses of blood stem cells. Blood 1997; 89: 2233-2258.

4 Krause DS, Theise ND, Collector MI, et al. Multi-organ, multi-lineage engraftment by a single bone marrowderived stem cell. Cell 2001; 105: 369-377.

5 Blau HM, Brazelton TR, Weimann JM. The evolving concept of a stem cell: entity or function? Cell 2001; 105: 829-841.

6 Denburg JA, Keith PK. Systemic aspects of chronic rhinosinusitis. Immunol Allergy Clin North Am 2004; 24: 87-102.

7 Cyr MM, Denburg JA. Systemic aspects of allergic disease: the role of the bone marrow. Curr Opin Immunol 2001; 13: 727-732.

8 Sehmi R, Baatjes AJ, Denburg JA. Hemopoietic progenitor cells and hemopoietic factors: potential targets for treatment of allergic inflammatory diseases. Curr Drug Targets Inflamm Allergy 2003; 2: 271-278.
9 Denburg JA, Dolovich J, Ohtoshi T, Cox G, Gauldie J, Jordana $M$. The microenvironmental differentiation hypothesis of airway inflammation. Am J Rhinology 1990; 4: 29-32.

10 Sehmi R, Howie K, Sutherland DR, Schragge W, O'Byrne PM, Denburg JA. Increased levels of CD34+ hemopoietic progenitor cells in atopic subjects. Am J Respir Cell Mol Biol 1996; 15: 645-654.

11 Sehmi R, Wood LJ, Watson R, et al. Allergen-induced increases in IL- 5 receptor $\alpha$-subunit expression on bone marrow-derived CD34+ cells from asthmatic subjects. A novel marker of progenitor cell commitment toward eosinophilic differentiation. J Clin Invest 1997; 100: 2466-2475.

12 Dorman SC, Efthimiadis A, Babirad I, et al. Sputum CD34+IL-5R $\alpha+$ cells increase after allergen: evidence for in situ eosinophilopoeisis. Am J Respir Crit Care Med 2004; 169: 573-577.

13 Southam DS, Widmer N, Ellis R, Hirota JA, Inman MD, Sehmi R. Increased eosinophil-lineage committed progenitors in the lung of allergen-challenged mice. J Allergy Clin Immunol 2005; 115: 95-102.

14 Strauss LC, Rowley SD, La Russa VF, Sharkis SJ, Stuart RK, Civin CI. Antigenic analysis of hematopoiesis. V. Characterization of My-10 antigen expression by normal lymphohematopoietic progenitor cells. Exp Hematol 1986; 14: 878-886.

15 Sutherland DR, Keating A. The CD34 antigen: structure, biology, and potential clinical applications. J Hematother 1992; 1: 115-129.

16 Sutherland DR, Anderson L, Keeney M, Nayar R, ChinYee I. The ISHAGE guidelines for CD34+ cell determination by flow cytometry. International Society of Hematotherapy and Graft Engineering. J Hematother 1996; 5: 213-226.

17 Healy L, May G, Gale K, Grosveld F, Greaves M, Enver T. The stem cell antigen CD34 functions as a regulator of hemopoietic cell adhesion. Proc Natl Acad Sci USA 1995; 92: 12240-12244.

18 Suzuki A, Andrew DP, Gonzalo JA, et al. CD34-deficient mice have reduced eosinophil accumulation after allergen exposure and show a novel crossreactive $90-\mathrm{kD}$ protein. Blood 1996; 87: 3550-3562.

19 Cheng J, Baumhueter S, Cacalano G, et al. Hematopoietic defects in mice lacking the sialomucin CD34. Blood 1996; 87: 479-490.

20 Terashima T, Wiggs B, English D, Hogg JC, van Eeden SF. Polymorphonuclear leukocyte transit times in bone marrow during streptococcal pneumonia. Am J Physiol 1996; 271: L587-L592.

21 Lawrence E, van Eeden S, English D, Hogg JC. Polymorphonuclear leukocyte (PMN) migration in streptococcal pneumonia: comparison of older PMN with those recently released from the marrow. Am J Respir Cell Mol Biol 1996; 14: 217-224.

22 Sato Y, van Eeden SF, English D, Hogg JC. Bacteremic pneumococcal pneumonia: bone marrow release and pulmonary sequestration of neutrophils. Crit Care Med 1998; 26: 501-509.

23 Sato Y, van Eeden SF, English D, Hogg JC. Pulmonary sequestration of polymorphonuclear leukocytes released 
from bone marrow in bacteremic infection. Am J Physiol 1998; 275: L255-L261.

24 Terashima T, Wiggs B, English D, Hogg JC, van Eeden SF. Phagocytosis of small carbon particles (PM10) by alveolar macrophages stimulates the release of polymorphonuclear leukocytes from bone marrow. Am J Respir Crit Care Med 1997; 155: 1441-1447.

25 Terashima T, English D, Hogg JC, van Eeden SF. Release of polymorphonuclear leukocytes from the bone marrow by interleukin-8. Blood 1998; 92: 1062-1069.

26 Nakagawa M, Terashima T, D'yachkova Y, Bondy GP, Hogg JC, van Eeden SF. Glucocorticoid-induced granulocytosis: contribution of marrow release and demargination of intravascular granulocytes. Circulation 1998; 98: 2307-2313.

27 van Eeden SF, Kitagawa Y, Sato Y, Hogg JC. Polymorphonuclear leukocytes released from the bone marrow and acute lung injury. Chest 1999; 116: Suppl. 1, 43S-46S.

28 Yamada M, Kubo H, Ishizawa K, Kobayashi S, Shinkawa M, Sasaki H. Increased circulating endothelial progenitor cells in patients with bacterial pneumonia: evidence that bone marrow derived cells contribute to lung repair. Thorax 2005; 60: 410-413.

29 Palange P, Testa U, Huertas A, et al. Circulating haemopoietic and endothelial progenitor cells are decreased in COPD. Eur Respir J 2006; 27: 529-541.

30 Terashima T, Amakawa K, Matsumaru A, van Eeden S, Hogg JC, Yamaguchi K. BAL induces an increase in peripheral blood neutrophils and cytokine levels in healthy volunteers and patients with pneumonia. Chest 2001; 119: 1724-1729.

31 Mukae H, Zamfir D, English D, Hogg JC, van Eeden SF. Polymorphonuclear leukocytes released from the bone marrow by granulocyte colony-stimulating factor: intravascular behavior. Hematol J 2000; 1: 159-171.

32 van Eeden SF, Terashima T. Interleukin 8 (IL-8) and the release of leukocytes from the bone marrow. Leuk Lymphoma 2000; 37: 259-271.

33 Suwa T, Hogg JC, English D, van Eeden SF. Interleukin-6 induces demargination of intravascular neutrophils and shortens their transit in marrow. Am J Physiol Heart Circ Physiol 2000; 279: H2954-H2960.

34 Murray L, Chen B, Galy A, et al. Enrichment of human hematopoietic stem cell activity in the CD34+Thy-1+Linsubpopulation from mobilized peripheral blood. Blood 1995; 85: 368-378.

35 Roberts AW, Metcalf D. Granulocyte colony-stimulating factor induces selective elevations of progenitor cells in the peripheral blood of mice. Exp Hematol 1994; 22: 1156-1163.

36 Jackson JD, Yan Y, Brunda MJ, Kelsey LS, Talmadge JE. Interleukin-12 enhances peripheral hematopoiesis in vivo. Blood 1995; 85: 2371-2376.

37 Grzegorzewski K, Komschlies KL, Mori M, et al. Administration of recombinant human interleukin-7 to mice induces the exportation of myeloid progenitor cells from the bone marrow to peripheral sites. Blood 1994; 83: 377-385.

38 Lord BI, Woolford LB, Wood LM, et al. Mobilization of early hematopoietic progenitor cells with BB-10010: a genetically engineered variant of human macrophage inflammatory protein-1 alpha. Blood 1995; 85: 3412-3415.

39 Honczarenko M, Le Y, Swierkowski M, Ghiran I, Glodek A, Silberstein LE. Human bone marrow stromal cells express a distinct set of biologically functional chemokine receptors. Stem Cells 2005; [Epub ahead of print].

40 Wang Y, Johnsen HE, Mortensen S, et al. Changes in circulating mesenchymal stem cells, stem cell homing factor, and vascular growth factors in patients with acute ST-elevation myocardial infarction treated with primary percutaneous coronary intervention. Heart 2005; [Epub ahead of print].

41 Hashimoto N, Jin H, Liu T, Chensue SW, Phan SH. Bone marrow-derived progenitor cells in pulmonary fibrosis. $J$ Clin Invest 2004; 113: 243-252.

42 Plantier L, Marchand-Adam S, Marchal-Somme J, et al. Defect of hepatocyte growth factor production by fibroblasts in human pulmonary emphysema. Am J Physiol Lung Cell Mol Physiol 2005; 288: L641-L647.

43 Phillips RJ, Burdick MD, Hong $\mathrm{K}$, et al. Circulating fibrocytes traffic to the lungs in response to CXCL12 and mediate fibrosis. J Clin Invest 2004; 114: 438-446.

44 O'Byrne PM, Dolovich J, Hargreave FE. Late asthmatic responses. Am Rev Respir Dis 1987; 136: 740-751.

45 Aalbers R, Kauffman HF, Vrugt B, et al. Bronchial lavage and bronchoalveolar lavage in allergen-induced single early and dual asthmatic responders. Am Rev Respir Dis 1993; 147: 76-81.

46 Aalbers R, De Monchy JG, Kauffman HF, et al. Dynamics of eosinophil infiltration in the bronchial mucosa before and after the late asthmatic reaction. Eur Respir J 1993; 6: 840-847.

47 Aalbers R, Kauffman HF, Vrugt B, Koeter GH, De Monchy JG. Allergen-induced recruitment of inflammatory cells in lavage 3 and $24 \mathrm{~h}$ after challenge in allergic asthmatic lungs. Chest 1993; 103: 1178-1184.

48 Gauvreau GM, Watson RM. O'Byrne PM. Kinetics of allergen-induced airway eosinophilic cytokine production and airway inflammation. Am J Respir Crit Care Med 1999; 160: 640-647.

49 Gauvreau GM, Lee JM, Watson RM, Irani AM, Schwartz LB, O'Byrne PM. Increased numbers of both airway basophils and mast cells in sputum after allergen inhalation challenge of atopic asthmatics. Am J Respir Crit Care Med 2000; 161: 1473-1478.

50 Sehmi R, Dorman S, Baatjes A, et al. Allergen-induced fluctuation in CC chemokine receptor 3 expression on bone marrow CD34+ cells from asthmatic subjects: significance for mobilization of haemopoietic progenitor cells in allergic inflammation. Immunology 2003; 109: 536-546.

51 Robinson DS, Damia R, Zeibecoglou K, et al. CD34+/ interleukin-5R $\alpha$ messenger RNA+ cells in the bronchial mucosa in asthma: potential airway eosinophil progenitors. Am J Respir Cell Mol Biol 1999; 20: 9-13.

52 Kim YK, Uno M, Hamilos DL, et al. Immunolocalization of CD34 in nasal polyposis. Effect of topical corticosteroids. Am J Respir Cell Mol Biol 1999; 20: 388-397.

53 Sergejeva S, Malmhall C, Lotvall J, Pullerits T. Increased number of CD34+ cells in nasal mucosa of allergic rhinitis patients: inhibition by a local corticosteroid. Clin Exp Allergy 2005; 35: 34-38. 
54 Kucia M, Jankowski K, Reca R, et al. CXCR4-SDF-1 signalling, locomotion, chemotaxis and adhesion. J Mol Histol 2004; 35: 233-245.

55 Linden M, Svensson C, Andersson M, et al. Circulating eosinophil/basophil progenitors and nasal mucosal cytokines in seasonal allergic rhinitis. Allergy 1999; 54: 212-219.

56 Otsuka H, Dolovich J, Befus AD, Telizyn S, Bienenstock J, Denburg JA. Basophilic cell progenitors, nasal metachromatic cells, and peripheral blood basophils in ragweedallergic patients. J Allergy Clin Immunol 1986; 78: 365-371.

57 Cyr MM, Hayes LM, Crawford L, Baatjes AJ, Keith PK, Denburg JA. The effect of desloratadine on eosinophil/ basophil progenitors and other inflammatory markers in seasonal allergic rhinitis: a placebo-controlled randomized study. Int Arch Allergy Immunol 2005; 138: 209-216.

58 Gibson PG, Dolovich J, Girgis-Gabardo A, et al. The inflammatory response in asthma exacerbation: changes in circulating eosinophils, basophils and their progenitors. Clin Exp Allergy 1990; 20: 661-668.

59 Otsuka H, Dolovich J, Befus AD, Bienenstock J, Denburg JA. Peripheral blood basophils, basophil progenitors, and nasal metachromatic cells in allergic rhinitis. Am Rev Respir Dis 1986; 133: 757-762.

60 Cameron L, Christodoulopoulos P, Lavigne F, et al. Evidence for local eosinophil differentiation within allergic nasal mucosa: inhibition with soluble IL-5 receptor. J Immunol 2000; 164: 1538-1545.

61 Wood LJ, Inman MD, Denburg JA, O’Byrne PM. Allergen challenge increases cell traffic between bone marrow and lung. Am J Respir Cell Mol Biol 1998; 18: 759-767.

62 Saito H, Howie K, Wattie J, et al. Allergen-induced murine upper airway inflammation: local and systemic changes in murine experimental allergic rhinitis. Immunology 2001; 104: 226-234.

63 Kopf M, Brombacher F, Hodgkin PD, et al. IL-5-deficient mice have a developmental defect in CD5+ B-1 cells and lack eosinophilia but have normal antibody and cytotoxic T cell responses. Immunity 1996; 4: 15-24.

64 Palframan RT, Collins PD, Williams TJ, Rankin SM. Eotaxin induces a rapid release of eosinophils and their progenitors from the bone marrow. Blood 1998; 91: 2240-2248.

65 Mould AW, Matthaei KI, Young IG, Foster PS. Relationship between interleukin-5 and eotaxin in regulating blood and tissue eosinophilia in mice. J Clin Invest 1997; 99: 1064-1071.

66 Wood LJ, Sehmi R, Gauvreau GM, et al. An inhaled corticosteroid, budesonide, reduces baseline but not allergen-induced increases in bone marrow inflammatory cell progenitors in asthmatic subjects. Am J Respir Crit Care Med 1999; 159: 1457-1463.

67 Upham JW, Hayes LM, Lundahl J, Sehmi R, Denburg JA. Reduced expression of hemopoietic cytokine receptors on cord blood progenitor cells in neonates at risk for atopy. $J$ Allergy Clin Immunol 1999; 104: 370-375.

68 Denburg JA, Hatfield HM, Cyr MM, et al. Fish oil supplementation in pregnancy modifies neonatal progenitors at birth in infants at risk of atopy. Pediatr Res 2005; 57: 276-281.
69 Rojas M, Xu J, Woods CR, et al. Bone marrow-derived mesenchymal stem cells in repair of the injured lung. Am J Respir Cell Mol Biol 2005; 33: 145-152.

70 Kotton DN, Ma BY, Cardoso WV, et al. Bone marrowderived cells as progenitors of lung alveolar epithelium. Development 2001; 128: 5181-5188.

71 Theise ND, Nimmakayalu M, Gardner R, et al. Liver from bone marrow in humans. Hepatology 2000; 32: 11-16.

72 Kotton DN, Fine A. Derivation of lung epithelium from bone marrow cells. Cytotherapy 2003; 5: 169-173.

73 Jiang Y, Jahagirdar BN, Reinhardt RL, et al. Pluripotency of mesenchymal stem cells derived from adult marrow. Nature 2002; 418: 41-49.

74 Suratt BT, Cool CD, Serls AE, et al. Human pulmonary chimerism after hematopoietic stem cell transplantation. Am J Respir Crit Care Med 2003; 168: 318-322.

75 Kleeberger W, Versmold A, Rothamel T, et al. Increased chimerism of bronchial and alveolar epithelium in human lung allografts undergoing chronic injury. Am J Pathol 2003; 162: 1487-1494.

76 Giangreco A, Reynolds SD, Stripp BR. Terminal bronchioles harbor a unique airway stem cell population that localizes to the bronchoalveolar duct junction. Am J Pathol 2002; 161: 173-182.

77 Weiss MJ, Burri PH. Formation of interalveolar pores in the rat lung. Anat Rec 1996; 244: 481-489.

78 Abe S, Boyer C, Liu X, et al. Cells derived from the circulation contribute to the repair of lung injury. Am J Respir Crit Care Med 2004; 170: 1158-1163.

79 Wang G, Bunnell BA, Painter RG, et al. Adult stem cells from bone marrow stroma differentiate into airway epithelial cells: potential therapy for cystic fibrosis. Proc Natl Acad Sci USA 2005; 102: 186-191.

80 Engelhardt JF, Schlossberg H, Yankaskas JR, Dudus L. Progenitor cells of the adult human airway involved in submucosal gland development. Development 1995; 121: 2031-2046.

81 Engelhardt JF. Stem cell niches in the mouse airway. Am J Respir Cell Mol Biol 2001; 24: 649-652.

82 Boers JE, Ambergen AW, Thunnissen FB. Number and proliferation of basal and parabasal cells in normal human airway epithelium. Am J Respir Crit Care Med 1998; 157: 2000-2006.

83 Borthwick DW, Shahbazian M, Krantz QT, Dorin JR, Randell SH. Evidence for stem-cell niches in the tracheal epithelium. Am J Respir Cell Mol Biol 2001; 24: 662-670.

84 Gregory CA, Prockop DJ, Spees JL. Non-hematopoietic bone marrow stem cells: molecular control of expansion and differentiation. Exp Cell Res 2005; 306: 330-335.

85 Orlic D, Kajstura J, Chimenti S, et al. Bone marrow cells regenerate infarcted myocardium. Nature 2001; 410: 701-705.

86 Kocher AA, Schuster MD, Szabolcs MJ, et al. Neovascularization of ischemic myocardium by human bone-marrow-derived angioblasts prevents cardiomyocyte apoptosis, reduces remodeling and improves cardiac function. Nat Med 2001; 7: 430-436.

87 Eglitis MA, Mezey E. Hematopoietic cells differentiate into both microglia and macroglia in the brains of adult mice. Proc Natl Acad Sci USA 1997; 94: 4080-4085. 